\title{
Efek Pemberian Ekstrak Kulit Jeruk Keprok (Citrus Reticulata) terhadap Cell-Cycle G1 Arrest dan Apoptosis pada Sel Kultur Retinoblastoma
}

\section{Citrus Peel Extract (Citrus reticulata) Effect on Cell-Cycle G1 Arrest and Apoptosis in Retinoblastoma Cell Culture}

\author{
Syarifah Rohaya ${ }^{1}$, Hariwati ${ }^{1}$, Lely Retno $W^{1}$, Hidayat Sujuti ${ }^{2}$ \\ ${ }^{1}$ Laboratorium Ilmu Kesehatan Mata Rumah Sakit Umum Daerah Dr. Saiful Anwar Malang \\ ${ }^{2}$ Laboratorium Ilmu Kesehatan Mata Fakultas Kedokteran Universitas Brawijaya Malang
}

\begin{abstract}
ABSTRAK
Retinoblastoma adalah kanker intraokular yang terjadi pada anak usia dini, disebabkan oleh terganggunya supresor tumor gen RB baik secara herediter maupun nonherediter. Tatalaksananya adalah enukleasi, eksentrasi, kemoterapi, laser fotokoagulasi, cryotherapi, dan radioterapi. Apabila tidak diobati hampir seluruh pasien mengalami proses desak ruang dan penyebaran tumor. Kemoterapi bukan merupakan pilihan terapi selektif karena hal ini semakin merusak sel normal pada jaringan yang normal. Sehingga peneliti mencari alternatif terapi seperti ekstrak kulit jeruk keprok yang memiliki fungsi sebagai anti karsinogenik, anti tumor, anti invasif dan anti metastasis. Penelitian ini merupakan analitik eksperimental pada sel kultur retinoblastoma yang dipapar dengan ekstrak kulit jeruk keprok. Sel kultur retinoblastoma dibagi menjadi 4 kelompok, yaitu kelompok kontrol, kultur+ekstrak kulit jeruk keprok dosis 10mg/mL, kultur+ekstrak kulit jeruk keprok dosis $20 \mathrm{mg} / \mathrm{mL}$ dan kultur+ekstrak kulit jeruk keprok dosis $40 \mathrm{mg} / \mathrm{mL}$. Diinkubasi selama 72 jam lalu dilakukan pengecatan dengan propidium iodide untuk diperiksa menggunakan flowcitometry. Hasil pemeriksaan dengan flowcitometry berupa gambaran histogram dari siklus sel dan apoptosis. Sel kultur retinoblastoma pada fase G1/S, kelompok kontrol $(15,03 \pm 3,03)$, kelompok ekstrak kulit jeruk keprok dosis $10 \mathrm{mg} / \mathrm{mL}(12,47 \pm 2,51), 20 \mathrm{mg} / \mathrm{mL}(12,30 \pm 1,33)$ dan $40 \mathrm{mg} / \mathrm{mL}(10,80 \pm 1,52)(p=0,027)$ menunjukkan bahwa ekstrak kulit jeruk keprok tidak menginduksi G1 arrest. Pada data apoptosis, kelompok kontrol $(35,0 \pm 3,96)$, kelompok ekstrak kulit jeruk keprok dosis $10 \mathrm{mg} / \mathrm{mL}(33,63 \pm 0,88)$, $20 \mathrm{mg} / \mathrm{mL}(38,48 \pm 8,96)$ dan $40 \mathrm{mg} / \mathrm{mL}(64,42 \pm 2,09)(p=0,000)$ menunjukkan bahwa pemberian ekstrak kulit jeruk keprok menginduksi apoptosis pada sel kultur retinoblastoma. Kulit buah jeruk keprok (Citrus reticulata) mengandung berbagai macam senyawa flavonoid, yang bertindak sebagai anti-karsinogenik, anti-tumor, anti-invasif dan anti-metastasis. Pemberian ekstrak kulit jeruk keprok tidak menginduksi cell-cycle G1 arrest tetapi menginduksi proses apoptosis.
\end{abstract}

Kata Kunci: Apoptosis, cell-cycle G1 arrest, ekstrak kulit jeruk keprok (Citrus reticulata), sel kultur retinoblastoma

\begin{abstract}
Retinoblastoma, an intraocular cancer occurring in early childhood, is caused by disruption in the tumor suppressor RB gene and can occur either hereditary or nonhereditary. The management involves enucleation, exenteration, chemotherapy, laser photocoagulation, cryotherapy and radiotherapy. If left untreated, almost all patients experience intracranial extension and disseminated disease. Chemotherapeutic agents are usually nonselective because these agents also damage normal cells in normal tissues. Therefore, the researchers search an alternative therapy such as citrus peel extract that has function as anti-carcinogenic, anti-tumor, anti-invasive, and anti-metastasis. This study is an experimental study on retinoblastoma cell cultures that are exposed to citrus peel extract. The retinoblastoma cell culture was divided in 4 groups, namely control group, cell culture $+10 \mathrm{mg} / \mathrm{ml}$ citrus peel extract, cell culture $+20 \mathrm{mg} / \mathrm{ml}$ citrus peel extract, and cell culture $+40 \mathrm{mg} / \mathrm{ml}$ citrus peel extract. All groups were incubated for 72 hours and propidium iodide staining was performed for flowcytometry analysis. The examination results through flowcytometry were histogram of cell cycle and apoptosis. Retinoblastoma cell culture in G1/S phase, control group $(15,03 \pm 3,03), 10 \mathrm{mg} / \mathrm{ml}$ citrus peel extract $(12,47 \pm 2,51), 20 \mathrm{mg} / \mathrm{ml}$ citrus peel extract $(12,30 \pm 1,33)$ and $40 \mathrm{mg} / \mathrm{ml}$ citrus peel extract $(10,80 \pm 1,52)$ with significant value $0,027(p<0,05)$ show that citrus peel extract do not induce $G 1$ arrest. On apoptosis data, control group $(35,0 \pm 3,96)$, $10 \mathrm{mg} / \mathrm{ml}$ citrus peel extract $(33,63 \pm 0,88), 20 \mathrm{mg} / \mathrm{ml}$ citrus peel extract $(38,48 \pm 8,96)$ and $40 \mathrm{mg} / \mathrm{ml}$ citrus peel extract $(64,42 \pm 2,09)(p=0,000)$ show that citrus peel extract can induce apoptosis in retinoblastoma cell culture. Citrus peel (Citrus reticulata) consist of flavonoids that act as anti-carcinogenic, anti-tumor, anti-invasive and anti-metastasis. Citrus peel extract do not induce of cell-cycle G1 arrest but induce apoptosis process.
\end{abstract}

Keywords: Apoptosis, cell-cycle G1 arrest, citrus peel extract (Citrus reticulata), human retinoblastoma cell culture

Jurnal Kedokteran Brawijaya, Vol. 28, No. 2, Agustus 2014; Korespondensi: Syarifah Rohaya. Bagian Ilmu Kesehatan Mata Rumah Sakit Umum Daerah Dr. Saiful Anwar Malang, Jl. Jaksa Agung Suprapto No. 2 Malang Tel. (0341) 366242 Email: syarifah_rohaya@yahoo.com 


\section{PENDAHULUAN}

Retinoblastoma merupakan kasus tumor pada anak-anak yang berakibat fatal, sebanyak $2 / 3$ kasus muncul sebelum akhir tahun ketiga. Tumor bersifat bilateral pada sekitar $30 \%$ kasus. Kasus-kasus ini bersifat herediter. Retinoblastoma bilateral secara khas didiagnosa pada tahun pertama kehidupan dan pada kasus unilateral didiagnosa pada umur antara 1-3 tahun $(1,2)$.

Gambaran klinis retinoblastoma yang sering muncul adalah leukokoria (white pupillary reflex), strabismus dan inflamasi okular. Gambaran klinis lain yang mungkin tampak antara lain heterochromia iris, hifema, perdarahan vitreous, selulitis orbita, glaukoma, proptosis dan hipopion $(3,4)$. Kegagalan diagnosa pada stadium awal akan menyebabkan kebutaan, deformitas kosmetik yang permanen dan pada kasus yang berat akan menyebabkan kematian, sehingga harus tanggap terhadap gejala dini retinoblastoma. Diagnosis dini dan pengobatan yang adekuat pada tumor yang masih terbatas intraokular dapat menghasilkan survival rate 90\%-95\%. Tanpa pengobatan, tumor ini akan berekstensi ke ekstraokular dan mempunyai prognosis yang buruk (5).

Penatalaksanaan retinoblastoma bertujuan untuk menyelamatkan jiwa penderita dan mempertahankan bola mata. Pilihan penatalaksanaan retinoblastoma sampai saat ini meliputi enukleasi, eksenterasi, kemoterapi, laser fotokoagulasi, krioterapi, externalbeam radiation dan plaque radiotherapy. Pada kasuskasus retinoblastoma yang telah mengalami metastase, sudah menyebar ke orbita atau nervus optikus maka dilakukan kemoterapi. Agen anti kanker ini memiliki rentang index terapi yang sempit sehingga memungkinkan timbulnya toksisitas pada jaringan normal (6).

Kulit buah jeruk keprok (Citrus reticulata) mempunyai berbagai macam senyawa flavonoid yang berpotensi sebagai agen kemopreventif. Golongan senyawa ini diketahui memiliki spektrum aktivitas biologis yang luas mencakup aktivitasnya sebagai anti-karsinogenik, antitumor, anti-invasif dan anti-metastasis. Kelompok senyawa flavonoid ini mengandung tangeretin, nobiletin, hesperidin, hesperetin dan naringin (7-9).

Tangeretin dan nobiletin dikatakan dapat menginduksi cell-cycle G1 arrest pada sel kanker kolon COLO 205 dan sel kanker payudara T47D dengan cara menghambat pada target Cdk 4 dan Cdk 2. Selain itu, tangeretin dalam buah jeruk dapat menginduksi apoptosis pada sel leukemia HL60 (10-14). Tangeretin dan nobiletin bersifat sitostatik, yaitu menghambat pertumbuhan sel tumor dan tidak bersifat toksik terhadap jaringan normal $(13,15,16)$. Kedua polimetoksi flavonoid ini bekerja menghambat proliferasi kultur sel dari karsinoma sel skuamosa, gliosarkoma, leukemia, melanoma, kanker kolorektal, kanker gaster dan kanker paru. Selain itu juga dilaporkan bahwa tangeretin dan nobiletin dapat menurunkan insiden tumor pada tikus. Secara in vivo, tangeretin dan nobiletin terbukti aman dalam mencegah terjadinya tumor. Sedangkan secara in vitro, tangeretin dan nobiletin terbukti dapat meningkatkan ikatan antar sel serta menghambat proliferasi pada sel kanker payudara MCF7/6(10).

Berdasarkan pada paparan diatas, peneliti ingin melakukan penelitian ekstrak kulit jeruk keprok (Citrus reticulata) terhadap sel retinoblastoma karena penelitian pada sel retinoblastoma merupakan penelitian awal. Sel kultur retinoblastoma dipapar dengan beberapa dosis ekstrak kulit jeruk keprok untuk mengetahui efeknya terhadap cell-cycle G1 arrest dan apoptosis pada sel kultur retinoblastoma.

\section{METODE}

Penelitian ini merupakan penelitian eksperimental in vitro, yaitu kultur sel jaringan retinoblastoma yang dipapar dengan ekstrak kulit jeruk keprok (Citrus reticulata). Subjek penelitian adalah jaringan retinoblastoma yang diambil dari penderita retinoblastoma di RSUD dr.Saiful Anwar Malang. Kultur sel retinoblastoma dibagi dalam 4 kelompok, yaitu kelompok kontrol (tidak mendapatkan paparan apapun), kelompok perlakuan 1 (paparan ekstrak kulit jeruk keprok dosis $10 \mathrm{mg} / \mathrm{mL}$ ), kelompok perlakuan 2 (paparan ekstrak kulit jeruk keprok dosis $20 \mathrm{mg} / \mathrm{mL}$ ) dan kelompok perlakuan 3 (paparan ekstrak kulit jeruk keprok dosis 40mg/mL). Keempat kelompok ini diamati setelah 72 jam.

Dosis ekstrak kulit jeruk keprok $(\mathrm{mg} / \mathrm{mL})$ dihitung dengan menggunakan rumus: (g solute)/ 1 mole $x$ (mole)/L $\times(L)$ atau FW $x$ molarity $x$ volume. Dosis ekstrak kulit jeruk keprok yang diberikan ditentukan berdasarkan "dose doubling design", yaitu $10 \mathrm{mg} / \mathrm{mL}, 20 \mathrm{mg} / \mathrm{mL}$ dan $40 \mathrm{mg} / \mathrm{mL}$.

\section{Kultur Jaringan Sel Retinoblastoma}

Jaringan sel retinoblastoma dicuci dengan PBS steril sebanyak 3 kali didalam laminar flow. Jaringan dicacah dalam media serum free hingga berukuran $1 \times 1 \mathrm{~mm}$. Suspensi jaringan (centrifuge) diputar dengan kecepatan 1200 rpm selama 7 menit. Supernatan dibuang sedangkan pellet diresuspensi dengan serum free dan dipipetting. Suspensi jaringan (centrifuge) diputar dengan kecepatan 1200 rpm selama 7 menit. Supernatan dibuang sedangkan pellet diresuspensi dengan media kultur dan dipipetting. Jaringan dimasukkan ke dalam plate kultur dan diinkubasi pada suhu $37^{\circ} \mathrm{C}$, kelembaban udara $95 \%$, dan $5 \% \mathrm{CO}_{2}$ selama 24 jam.

\section{Ekstrak Kulit Jeruk Keprok}

Kulit jeruk keprok yang akan dikeringkan dicuci bersih, lalu dipotong kecil-kecil. Selanjutnya dioven dengan suhu $80^{\circ} \mathrm{C}$ atau dengan panas matahari sampai kering. Setelah kering, diblender sampai halus, ditimbang sebanyak 100gr. Dimasukkan 100gr kulit jeruk keprok kering ke dalam gelas Erlenmeyer ukuran 1 liter, kemudian direndam dengan etanol sampai volume $1000 \mathrm{ml}$. Kocok sampai benar-benar tercampur. Didiamkan 1 malam sampai mengendap. Diambil lapisan atas campuran etanol dengan zat aktif yang sudah terambil. Dimasukkan dalam labu evaporator 1 liter. Pasang labu evaporator pada evaporator. Water bath diisi dengan air sampai penuh. Biarkan larutan etanol memisahkan zat aktif yang sudah ada dalam labu. Ditunggu sampai aliran etanol berhenti menetes pada labu penampung. Hasil yang diperoleh kira-kira 1/5 dari kulit jeruk keprok yang sudah dikeringkan. Hasil ekstraksi dimasukkan dalam botol plastik/kaca dan disimpan dalam freezer.

\section{Dosis Ekstrak Kulit Jeruk Keprok}

Pembuatan dosis ekstrak kulit jeruk keprok didahului dengan pembuatan larutan, yaitu larutan ekstrak kulit jeruk keprok yang telah diencerkan dengan air hingga 
homogen. Buat larutan stok sebanyak $500 \mathrm{mg} / \mathrm{mL}$. Sebanyak 500mg ekstrak kulit jeruk keprok diencerkan dengan $5 \mathrm{~mL}$ air. Rumus yang digunakan: V1.M1=V2.M2, V1 adalah volume larutan sebelum pengenceran, M1 adalah molaritas larutan sebelum pengenceran, V2 adalah volume larutan setelah pengenceran dan M2 adalah molaritas larutan setelah pengenceran. Kemudian larutan ekstrak ini dicampur dengan DMEM dan diteteskan pada kelompok perlakuan.

\section{Perlakuan Sel Kultur Jaringan Retinoblastoma}

Sel kultur didalam plate kultur ditetesi dengan tripsinEDTA sehingga sel kultur dapat lepas dari plate kultur. Kemudian dilakukan centrifuge. Setelah itu supernatan dibuang, pellet dicampur dengan FBS. Kemudian lakukan resuspensi sampai homogen, ambil $100 \mathrm{~mL}$ dan masukkan ke tiap well. Pada kelompok perlakuan, sel kultur ini dipapar dengan ekstrak kulit jeruk keprok dosis $10 \mathrm{mg} / \mathrm{mL}$, $20 \mathrm{mg} / \mathrm{mL}$ dan $40 \mathrm{mg} / \mathrm{mL}$. Dilakukan analisa siklus sel fase G1/S dan apoptosis pada sel kultur retinoblastoma dengan menggunakan flowcytometry pada kelompok kontrol dan kelompok perlakuan setelah $72 \mathrm{jam}$.

\section{Cell Cycle Analysis dan Apoptosis Menggunakan} Propidium lodide (PI) Staining

Sel dikultur dalam 24 well plate dengan densitas 300,000 sel/well dalam $1 \mathrm{ml}$ medium pertumbuhan. Beri 1 dan 2 mM AICAR, kemudian sel disentrifus pada kecepatan 1200 rpm selama 5 menit. Dicuci 2 kali dengan $1 \mathrm{ml}$ PBS dingin. Tambahkan $2 \mathrm{ml}$ ethanol dingin $75 \%$ pada saat sel divortex. Sel difiksasi 1 malam. Esok harinya, sel disentrifus lagi, kemudian dimasukkan ke dalam $2 \mathrm{ml}$ PBS. Ditambahkan $100 \mathrm{ml}$ DNase-free $(200 \mathrm{ml} / \mathrm{ml})$, RNase A, diinkubasi pada suhu $37^{\circ} \mathrm{C}$ selama 30 menit. Ditambahkan $100 \mathrm{ml} \mathrm{PI}$, diinkubasi pada suhu ruangan selama 10 menit. Sampel dibaca pada flowcitometer (BD FACSCalibur).

\section{Rancangan Analisa Data}

Pada penelitian ini digunakan uji one-way ANOVA, uji rentang ganda (multiple comparison, Tukey), uji korelasi dan uji regresi linier. Kemaknaan ditentukan berdasarkan nilai $p<0,05$. Data disajikan dalam bentuk tabulasi dengan menggunakan program SPSS 15.0 for windows.

\section{HASIL}

Jaringan retinoblastoma yang masih heterogen dikultur dan dilakukan subkultur untuk mendapatkan sel-sel yang homogen. Pada hasil kultur tampak sel-sel retinoblastoma lebih kecil dan bulat (Gambar 1).

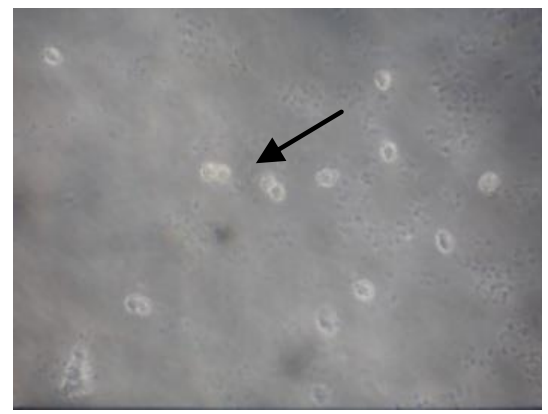

Gambar 1. Sel kultur retinoblastoma penderita, sel tampak homogen, lebih kecil dan lebih bulat (dilihat menggunakan mikroskop cahaya dengan pembesaran 400x)
Pada Gambar 2 tampak bahwa fase G1 (M1) memiliki tinggi yang hampir sama baik pada kelompok kontrol dan kelompok ekstrak kulit jeruk keprok dosis $10 \mathrm{mg} / \mathrm{mL}$, sedangkan kelompok ekstrak kulit jeruk keprok dosis $20 \mathrm{mg} / \mathrm{mL}$ sedikit lebih rendah dari dosis $10 \mathrm{mg} / \mathrm{mL}$ dan kelompok ekstrak kulit jeruk keprok dosis $40 \mathrm{mg} / \mathrm{mL}$ sedikit lebih rendah dari dosis $20 \mathrm{mg} / \mathrm{mL}$. Pada gambaran sub-G1 (apoptosis) tampak rendah pada kelompok kontrol dan kelompok ekstrak kulit jeruk keprok dosis $10 \mathrm{mg} / \mathrm{mL}$, pada kelompok ekstrak kulit jeruk keprok dosis $20 \mathrm{mg} / \mathrm{mL}$ dan 40 $\mathrm{mg} / \mathrm{mL}$ tampak gambaran sub-G1 (apoptosis) yang lebih tinggi.
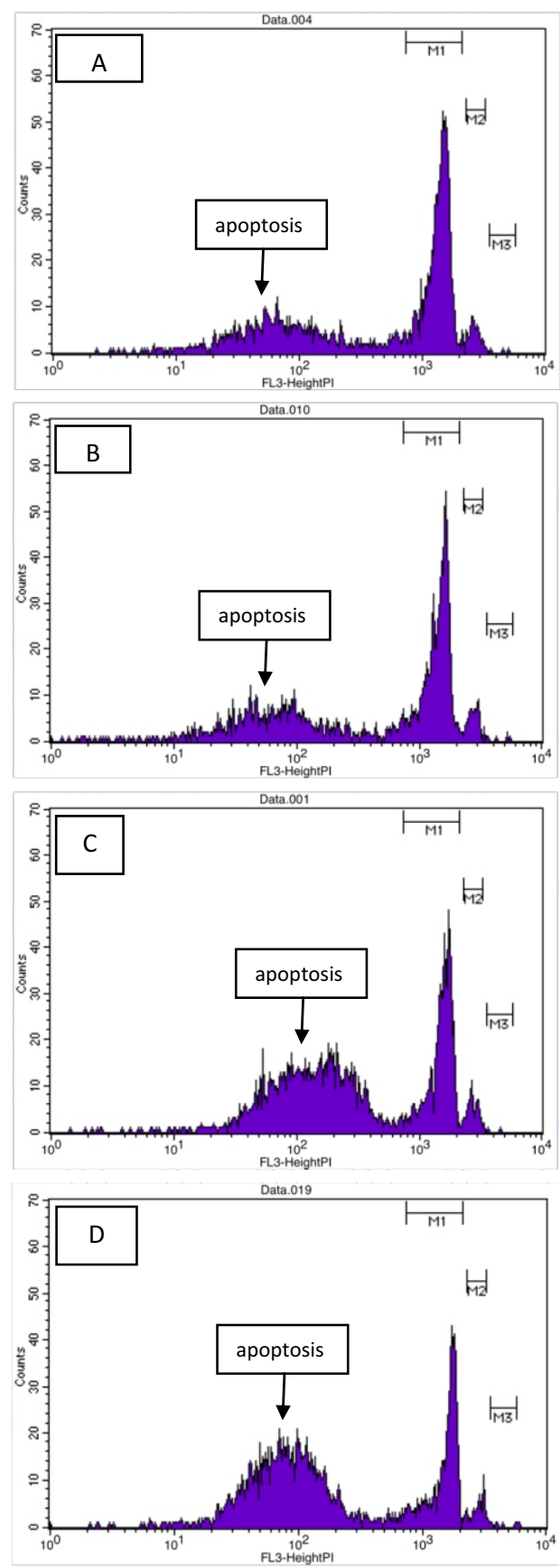

Gambar 2. Gambaran histogram pada kelompok perlakuan

Keterangan:

a. Gambaran histogram sel kultur retinoblastoma pada kelompok kontrol

b. Ekstrak kulit jeruk keprok dosis $10 \mathrm{mg} / \mathrm{m}$

c. Ekstrak kulit jeruk keprok dosis $20 \mathrm{mg} / \mathrm{ml}$

d. Ekstrak kulit jeruk keprok dosis $40 \mathrm{mg} / \mathrm{ml}$ 
Pada Gambar 2 didapatkan gambaran histogram sel kultur retinoblastoma pada kelompok kontrol pada fase G1 (M1) lebih tingi $(55,80 \%)$ dan gambaran apoptosis lebih rendah $(34,95 \%)$. Pada gambaran histogram dengan perlakuan ekstrak kulit keprok dosis 10mg/ml fase G1 (M1) 54,82\% dengan apoptosis 33,63\%. Pada perlakuan ekstrak kulit kulit jeruk keprok dosis $20 \mathrm{mg} / \mathrm{ml}$ sedikit lebih rendah dari dosis $10 \mathrm{mg} / \mathrm{mL}(51,48 \%)$ dengan gambaran apoptosis yang lebih tinggi dari dosis $10 \mathrm{mg} / \mathrm{mL}(38,48 \%)$, dan Gambaran histogram sel kultur retinoblastoma pada kelompok ekstrak kulit jeruk keprok dosis $40 \mathrm{mg} / \mathrm{mL}$ fase G1 (M1) paling rendah dari seluruh perlakuan (27,46\%) dengan gambaran apoptosis yang paling tinggi (64,42\%).

Pada Tabel 1 tampak bahwa fase G1/S pada kelompok ekstrak kulit jeruk keprok dosis $10 \mathrm{mg} / \mathrm{mL}$ lebih rendah daripada kelompok kontrol. Kelompok ekstrak kulit jeruk keprok dosis $20 \mathrm{mg} / \mathrm{mL}$ sedikit mengalami penurunan bila dibandingkan dengan dosis $10 \mathrm{mg} / \mathrm{mL}$. Pada kelompok ekstrak kulit jeruk keprok dosis $40 \mathrm{mg} / \mathrm{mL}$ pada fase $\mathrm{G} 1 / \mathrm{S}$ mengalami penurunan yang lebih besar.

Tabel 1. Distribusi sel kultur retinoblastoma pada fase G1/S dan apoptosis sel kultur retinoblastoma

\begin{tabular}{lcc}
\hline $\begin{array}{c}\text { Perlakuan Ekstrak Kulit } \\
\text { Jeruk Keprok (Dosis) }\end{array}$ & $\begin{array}{c}\text { Distribusi Sel Kultur } \\
\text { Retinoblastomapada } \\
\text { Fase G1/S }\end{array}$ & $\begin{array}{c}\text { Apoptosis Sel Kutur } \\
\text { Retinoblastoma }\end{array}$ \\
\hline $\begin{array}{l}\text { Kontrol } \\
\text { Ekstrak kulit jeruk keprok }\end{array}$ & $15,03 \pm 3,03$ & $35,0 \pm 3,96$ \\
dosis $10 \mathrm{mg} / \mathrm{mL}$ & $12,47 \pm 2,51$ & $33,63 \pm 0,88$ \\
$\begin{array}{l}\text { Ekstrak kulit jeruk keprok } \\
\text { dosis } 20 \mathrm{mg} / \mathrm{mL}\end{array}$ & $12,30 \pm 1,33$ & $38,48 \pm 8,96$ \\
$\begin{array}{l}\text { Ekstrak kulit jeruk keprok } \\
\text { dosis } 40 \mathrm{mg} / \mathrm{mL}\end{array}$ & $10,80 \pm 1,52$ & $64,42 \pm 2,09$ \\
& $\mathbf{p}$-value=0,027 & p-value=0,000 \\
\hline
\end{tabular}

Berdasarkan hasil uji one-way ANOVA dikatakan adanya perbedaan yang signikan antara efek pemberian ekstrak kulit jeruk keprok dengan jumlah sel pada fase $\mathrm{G} 1 / \mathrm{S}$ $(p=0,027)$. Dari hasil uji Tukey didapatkan bahwa kelompok ekstrak kulit jeruk keprok dosis $10 \mathrm{mg} / \mathrm{mL}$ dan $20 \mathrm{mg} / \mathrm{mL}$ tidak berbeda signifikan dari kelompok kontrol $(p=0,221$ dan $p=0,175)$, sedangkan kelompok ekstrak kulit jeruk keprok dosis $40 \mathrm{mg} / \mathrm{mL}$ berbeda signifikan bila dibandingkan dengan kelompok kontrol $(p=0,017)$.

Pada Kelompok ekstrak kulit jeruk keprok dosis $10 \mathrm{mg} / \mathrm{mL}$, jumlah sel yang mengalami apoptosis sedikit menurun bila dibandingkan dengan kelompok kontrol. Sebaliknya pada kelompok ekstrak kulit jeruk keprok dosis $20 \mathrm{mg} / \mathrm{mL}$ mulai didapatkan peningkatan jumlah sel yang apoptosis daripada kelompok kontrol. Pada kelompok ekstrak kulit jeruk keprok dosis $40 \mathrm{mg} / \mathrm{mL}$, jumlah sel yang mengalami apoptosis makin meningkat.

Dari uji one-way ANOVA didapatkan perbedaan yang signifikan antara efek pemberian ekstrak kulit jeruk keprok dengan jumlah sel yang apoptosis $(p=0,000)$. Dari hasil uji Tukey, pada kelompok ekstrak kulit jeruk keprok dosis $10 \mathrm{mg} / \mathrm{mL}$ dan $20 \mathrm{mg} / \mathrm{mL}$ tidak berbeda signifikan ( $p=0,965$ dan $p=0,634)$ bila dibandingkan dengan kelompok kontrol. Sebaliknya antara kelompok kontrol dengan kelompok ekstrak kulit jeruk keprok dosis $40 \mathrm{mg} / \mathrm{mL}$ memiliki perbedaan yang signifikan $(p=0,000)$.
Dari uji korelasi didapatkan nilai $r=-0,554$ dan $p=0,002$ maka dapat dikatakan bahwa peningkatan dosis ekstrak kulit jeruk keprok akan menyebabkan penurunan $\mathrm{G} 1 / \mathrm{S}$ kultur retinoblastoma. Pada uji regresi didapatkan hasil bahwa $1 \mathrm{mg} / \mathrm{mL}$ ekstrak kulit jeruk keprok dapat menurunkan G1/S kultur retinoblastoma sebesar 0,095. Sekitar 30,7\% penurunan jumlah sel kultur retinoblastoma pada fase $\mathrm{G} 1 / \mathrm{S}$ dipengaruhi oleh faktor ekstrak kulit jeruk keprok.

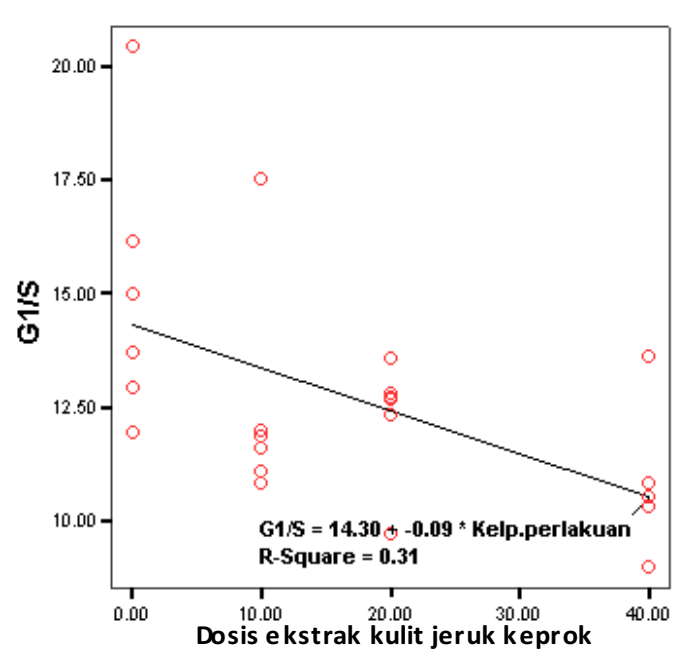

Gambar 3. Grafik linieritas ekstrak kulit jeruk keprok terhadap jumlah sel kultur retinoblastoma pada fase G1/S

Dari hasil uji korelasi antara ekstrak kulit jeruk keprok dengan apoptosis didapatkan adanya hubungan antara ekstrak kulit jeruk keprok dengan apoptosis $(r=0,861$, $p=0,002$ ), semakin tinggi dosis ekstrak kulit jeruk keprok maka jumlah sel yang apoptosis akan makin meningkat. Berdasarkan uji regresi dikatakan bahwa setiap $1 \mathrm{mg} / \mathrm{mL}$ ekstrak kulit jeruk keprok dapat meningkatkan apoptosis sebesar 0,778. Selain itu, ekstrak kulit jeruk keprok memiliki pengaruh yang besar terhadap apoptosis yaitu sebesar $74,1 \%$.

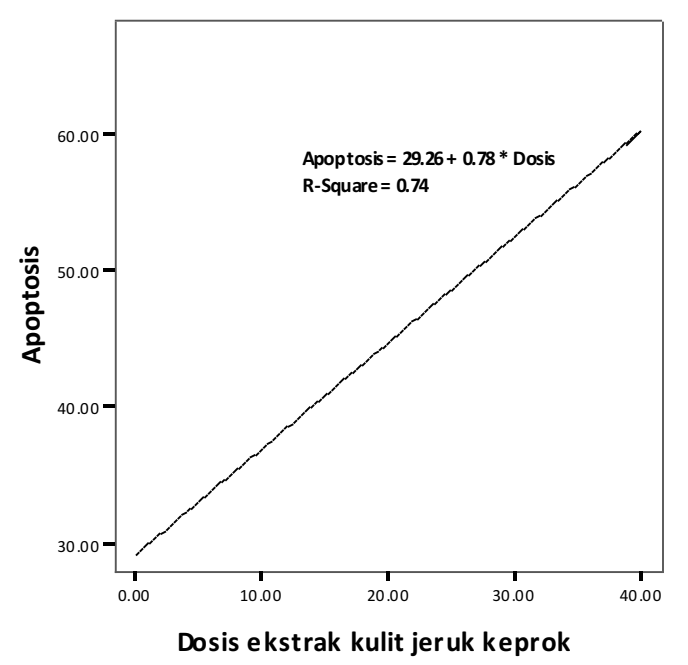

Gambar 4. Grafik linieritas antara ekstrak kulit jeruk keprok dengan apoptosis pada sel kultur retinoblastoma 


\section{DISKUSI}

Hasil dari penelitian ini didapatkan jumlah sel pada fase G1/S yang menurun setelah terpapar ekstrak kulit jeruk keprok. Hal ini menandakan adanya penurunan jumlah sel yang masuk ke fase $S$ untuk melakukan sintesa DNA. Penurunan jumlah sel ini dapat disebabkan oleh proses apoptosis atau cell-cycle G1 arrest. Pan melakukan penelitian tangeretin terhadap sel karsinoma kolorektal manusia (COLO 205) dan didapatkan hasil adanya cellcycle G1 arrest. Protein-protein yang berperan dalam meregulasi fase G1/S adalah Cdk 2, Cdk 4, Cdk inhibitor p21 dan p27. Pada penelitian ini terbukti bahwa tangeretin dapat menurunkan aktivitas Cdk 2 dan Cdk 4 dalam 48 jam serta dapat meningkatkan aktivitas Cdk inhibitor p21 dan p27 sehingga dapat menginduksi terjadinya cell-cycle G1 arrest. Hambatan terhadap aktivitas Cdk 2 dan Cdk 4 menyebabkan jumlah sel karsinoma pada fase G1 meningkat, sedangkan pada fase $\mathrm{S}$ dan $\mathrm{G} 2 / \mathrm{M}$ jumlah sel karsinomanya mengalami penurunan. Pada penelitian kami memberikan hasil yang berbeda dari hasil penelitian Pan yaitu jumlah sel pada fase G1 dan S menurun sehingga dapat dikatakan bahwa cell-cycle G1 arrest tidak terjadi tetapi terjadi proses apoptosis. Hal ini tampak pada hasil flowcytometry dimana didapatkan sel yang mengalami apoptosis pada kelompok ekstrak kulit jeruk keprok dosis $40 \mathrm{mg} / \mathrm{mL}$ lebih banyak jumlahnya daripada kelompok kontrol $(13,14)$.

Hirano melakukan penelitian tangeretin terhadap sel leukemia HL-60 dan didapatkan hasil bahwa tangeretin dapat menghambat pertumbuhan sel leukemia HL-60 melalui proses apoptosis. Apoptosis ini terjadi 24 jam setelah terpapar tangeretin. Efek tangeretin ini dapat menyebabkan defragmentasi DNA dan hambatan pertumbuhan yang ditandai dengan adanya ion seng $\left(\mathrm{Zn}^{2+}\right)$ dan dapat menghambat aktivitas $\mathrm{Ca}^{2+}$-dependent endonuclease. Kematian sel yang diinduksi oleh ion kalsium $\left(\mathrm{Ca}^{2+}\right)$ tergantung pada peningkatan konsentrasi ion kalsium intraseluler sehingga akan menyebabkan terjadinya proses nekrosis. Konsentrasi ion kalsium intraseluler yang lebih rendah akan menyebabkan kematian sel melalui proses apoptosis. Kerusakan atau defragmentasi DNA terjadi sebagai akibat dari adanya

\section{DAFTAR PUSTAKA}

1. Rosdiana N. Retinoblastoma Familial. Indonesian Journal of Cancer. 2009; 3(1): 33-36.

2. Paduppai S. Characteristic of Retinoblastoma Patients at Wahidin Sudirohusodo Hospital 2005-2010. The Indonesian Journal of Medical Science. 2010; 2(1): 17.

3. Raab EL. Pediatric Ophthalmology and Strabismus in Basic and Clinical Science Course. San Francisco: American Academy of Opthalmology; 2012; pp. 390399.

4. Rosdiana N. Gambaran Klinis dan Laboratorium Retinoblastoma. Sari Pediatri. 2011; 12(5): 319-322.

5. Honavar. Emerging Option in the Management of Advanced Intraocular Retinoblastoma. British Journal of Ophthalmology. 2009; 93(7): 848-849.

6. Shields CLand Shields JA. Diagnosis and Management of Retinoblastoma. Cancer Control. 2004; 11(5): 317327. perubahan konsentrasi ion kalsium intraseluler yang bersifat sitotoksik sehingga dapat mengakibatkan terjadinya disfungsi dari mitochondria. Disfungsi mitochondria ditandai dengan adanya kerusakan dari potensial mitochondria transmembrane dan terbukanya permeability transition pores dari mitochondria. Sehingga melepaskan berbagai macam protein ke dalam sitosol misalnya sitokrom c yang berfungsi untuk mengaktifkan caspase-9. Selanjutnya caspase-9 akan mengaktifkan caspase-3 dan caspase eksekusioner lain yaitu caspase- 6 dan caspase-7. Dengan teraktivasinya caspase eksekusioner akan mengaktifkan jalur apoptosis (12).

Kulit buah jeruk keprok (Citrus reticulata) mengandung berbagai macam senyawa flavonoid. Flavonoid diketahui memiliki spektrum aktivitas biologis yang luas mencakup aktivitasnya sebagai anti-karsinogenik, anti-tumor, antiinvasif dan anti-metastasis. Kelompok senyawa flavonoid ini mengandung tangeretin, nobiletin, hesperidin, hesperetin dan naringin. Tangeretin merupakan flavonoid utama pada kulit jeruk keprok, yaitu sekitar 87,5\%. Penelitian yang dilakukan oleh Karen terhadap tangeretin dan nobiletin pada cell line kanker kolon dan payudara, disimpulkan bahwa tangeretin dan nobiletin dapat menghambat $50-70 \%$ proliferasi sel tumor dan menginduksi terjadinya G1 arrest. Sebaliknya hasil penelitian yang dilakukan oleh Hirano (1995) menyatakan bahwa tangeretin dapat menghambat pertumbuhan sel leukemia HL-60 melalui proses apoptosis. Nobiletin dilaporkan juga memiliki efek imunomodulator, anti inflamasi, menghambat sel kanker mammae manusia, anti hepatitis C virus. Hesperidin bekerja meningkatkan integritas vascular, menurunkan permeabilitas kapiler, menurunkan kadar kolesterol dan anti kanker. Naringin dapat menurunkan kadar kolesterol, anti kanker, pada tikus terbukti sebagai antiulcer pada lesi gaster yang diinduksi etanol. Tangeretin, nobiletin, naringin dan hesperidin dilaporkan memiliki efek kemopreventif melalui modulasi aktivitas CYP1A2. Pada penelitian yang kami lakukan, zat-zat aktif ini tidak diekstrak secara terpisah karena tidak tersedianya sarana dan biaya yang mahal. Hal ini merupakan kelemahan pada penelitian kami ini $(8,10,15)$.

7. Perdana AN, Anita PD, Diah APKW, Sugeng R, dan Edy M. Mekanisme Penekanan Ekspresi N-Ras Ekstrak Kulit Jeruk Keprok (Citrus reticulata) sebagai Agen Kemopreventif. Jurnal Farmasi Indonesia. 2009; 4(3): 104-115.

8. Meiyanto E, Hermawan A, and Anindyajati. Natural Products for Cancer-Targeted Therapy: Citrus Flavonoids as Potent Chemopreventive Agents. Asian Pacific Journal of Cancer Prevention. 2012; 13(2): 427436.

9. Yunas SR, Latifah N, Rokhman MR, Fitriasari A, dan Meiyanto Edy. Penggunaan Ekstrak Etanolik Kulit Buah Jeruk Mandarin (Citrus reticulata) untuk Meningkatkan Sensitivitas Sel Kanker Payudara MCF-7 terhadap Agen Kemoterapi Doxorubicin. Pharmacon. 2007; 8(2): 64-69.

10. Morley KL, Ferguson PJ, and Koropatnick J. Tangeretin and Nobiletin Induce G1 cell Cycle Arrest but Not Apoptosis in Human Breast and Colon Cancer Cells. Cancer Letters. 2007; 251: 168-178. 
11. Pan MH, Chen WJ, Lin-Shiau SY, Ho CT, and Lin JK. Tangeretin Induces Cell-Cycle G1 Arrest Through Inhibiting Cyclin-Dependent Kinases 2 dan 4 Activities as Well as Elevating Cdk Inhibitors p21and p27 in Human Colorectal Carcinoma Cells. Carcinogenesis. 2002; 23(10): 1677-1684.

12. Hirano T, Abe K, Gotoh M, and Oka K. Citrus Flavone Tangeretin Inhibits Leukaemic HL-60 Cell Growth Partially through Induction of Apoptosis with Less Cytotoxicity on Normal Lymphocytes. British Journal of Cancer. 1995; 72(6): 1380-1388.
13. Pan $\mathrm{MH}$ and Ho CT. Chemopreventive Effects of Natural Dietary Compounds on Cancer Development. Chem Soc Rev. 2008; 37(11): 2558-2574.

14. Satsu H, Hiura Y, Mochizuki K, Hamada M, and Shimizu M. Activation of Pregnan X Receptor and Induction of MDR1 by Dietary Phytochemicals. Journal of Agricultural and Food Chemistry. 2008; 56(13): 53665373.

15. Lu Y, Zhang C, Bucheli P, and Wei D. Citrus Flavonoids in Fruit and Traditional Chinese Medicinal Food Ingredients in China. Plant Food for Human Nutrition. 2006; 61(2): 57-65. 